\title{
REFERENDUM FOR SELF-TAXATION AS A FORM OF PARTICIPATION OF COMMUNE RESIDENTS IN THE SHAPING OF ITS REVENUES
}

\author{
EWA KONIUSZEWSKA ${ }^{1}$
}

\begin{abstract}
The article is devoted to the issue of the referendum on self-taxation as a form of participation of the commune' residents in the shaping of the income level of their self-governing community. The basic objective of the study is to analyze the normative material aimed at answering the question to what extent, and under what conditions, the residents of a commune can realistically create the level of income of their local government units. An equally important problem is the identification of factors determining the initiation of the referendum procedure and affecting its effective course. The considerations undertaken are to justify the thesis that the actual use of the institution of a referendum on self-taxation in local communities is incidental. In the conducted research, a method of analyzing the legal text, the acquis of the jurisprudence and the doctrine was used.
\end{abstract}

\section{Keywords}

Direct democracy; participation; referendum' self-taxation

JEL Classification: D63, H71, K34

\section{Introduction}

The purpose of this paper is to analyze legal regulations defining the conditions for initiating a referendum procedure in the subject of self-taxing of residents of a

1 Doctor of Law, Assistant Professor in Department of Self-Government Law, Faculty of Law and Administration, University of Szczecin, Poland, Member of Center for Information and Research Organization in Public Finance and Tax Law of Central and Eastern European Countries. Contact email: ewa.koniuszewska@usz. edu.pl. 
commune for public purposes and the requirements of its legal course. Attention was paid to factors influencing taking the initiative to conduct a referendum and those decisive as regards the closing of the procedure with a conclusive outcome. The structure of the study has been adapted to the delineated research field. The starting point was a presentation of general issues of an introductory nature. Then, the considerations were made to confirm the thesis that despite the fact that normative foundations of the institution of the referendum on self-taxing have been formed, its actual use is marginal. For the purpose of the conducted research in the indicated scope, the method employed was the analysis of legal acts, judicial and administrative case law and doctrinal views. Research results presented in particular in the following publications were taken into account:

\section{Local Referendum - General Remarks}

A local referendum is one of the forms of direct exercise of power by members of the local government community. Using the institution of a referendum, residents of local government units can exercise their right to participate in the management of public affairs (Olejniczak-Szałowska, 2010: 189). The essence of the referendum is the general and direct participation of members of self-governing communities expressing their will, each of whom has one vote and the will of the majority decides. The legislator introduced a material definition and a formal definition of a local referendum. In material terms, it is an expression in the form of a vote of the residents' will regarding the way of resolving a case concerning this community. On the other hand, in formal terms, this is giving positive or a negative answer on the official ballot to the question or questions asked or making a choice between the proposed variants (Zimmermann, 2005: 216). The literature draws attention to the characteristic features of the institution of a referendum, which include: direct participation of citizens in expressing their views, having only one vote, recognizing the will of the majority of all equal citizens as decisive in the settlement of cases (Mordwiłko, 1998: 176).

The normative shape of the institution of a local referendum is determined by the provisions of Art. 170 of the Constitution of the Republic of Poland (Act of 2 April 1997), Art. $3 / 2$ of the European Charter of Local Self-Government, as well as provisions of constitutional acts (Act on commune self-government, Law on county self-government, Law on voivodship self-government) and the act on the local referendum (Act on the local referendum). Pursuant to the provisions of Art. 170 of the Constitution decisions through a referendum can be made by members of the self-governing community. The right to express their will, which they enjoy, is a public personal right of a political nature, and its essence is the right of every 
resident to participate in the direct exercise of public authority at the local level (Voivodeship Administrative Court: III SA/Gd 183/16). The decision-making right guaranteed to members of the self-governing community can be implemented in matters concerning the given community, including the dismissal of territorial selfgovernment body coming from direct elections. In accordance with the content of Art. 170 of the Constitution, principles of and procedures for conducting a local referendum shall be specified by statute. However, the ordinary legislator may not limit the scope of the local referendum in question, because in reality, it may apply to any matter relevant to the self-governing community. On the other hand, the issue underlying the initiation of a referendum cannot be private, nor can it only be relevant to particular individuals, it should be important for the community (Skoczylas, Piątek, 2016: 947).

The material scope of a local referendum was specified in Art. 2 of the Act on the local referendum. It included: matters of dismissal of the decision-making body of a given unit; the mode of resolving a case concerning this community, falling within the scope of tasks and competencies of the bodies of a given unit; other important matters regarding the social, economic or cultural ties that bind this community. In addition, at the level of the commune, the following matters were included in the material scope of the referendum: dismissal of the commune head (mayor, president of the city); self-taxation of residents for public purposes falling within the scope of tasks and competencies of commune bodies.

The legislator included self-taxation of residents for public purposes in the catalog of issues that may be the subject of a local referendum. A referendum in this matter is obligatory, which is confirmed by the provisions of Art. 54/2 of the Act on commune self-government. According to the aforementioned regulation, the income of the commune may also include inflows from residents' self-taxing. Selftaxation can only take place through a commune referendum.

Referring to the nature of the proceeds from self-taxation as a source of commune's income, it is necessary to recall the views on this subject presented in the doctrine. Representatives of science emphasize that self-taxation cannot be equated with the institution of tax. Tax features include, among others, its mandatoriness and unilateral determination. In the case of self-taxation, these features are difficult to indicate in the strict sense of these concepts. The will of the residents determines the introduction of the institution in question and not the exercise of powers by State authorities. In addition, self-taxation seems to be devoid of legal sanction. In addition, the source of a tax obligation may only be the law, while the source of an obligation in the field of self-taxation is a commune referendum (Brzeziński, 1995: 219). The principle of statutory exclusivity in matters of burdens with the nature of public levies results directly from the Constitution. The problem of 
territorial self-government tax authority must be set out in statutes where the state shares its financial authority with the self-governing community. The admissibility of imposing public fees by the commune authorities is conditioned by the consent of the residents on whom the public fee is to be imposed, previously expressed in a referendum (Gliniecka, 2007: 44). In doctrine, however, a different view was presented, according to which the institution of self-taxation is not compatible with the Constitution because the regulations contained in its Art. 217 determine the exclusivity of the Act in the field of imposing levying burdens (KornbergerSokołowska, 2013: 64).

Self-taxation is treated as the basic local government unit's collection of funds for public purposes important to this local community (Gomułowicz, 2013: 147). In the literature on the subject, public purposes are associated with the performance of tasks, therefore the income from self-taxation of residents must serve the implementation of a specific task. This means that self-taxation cannot have the character of a fixed income for communes. The performance of the task for which funding was obtained using this institution is tantamount to the expiration of this form of communal income (Kryczko, 2013: 756).

The premise justifying the use of the institution of a referendum on selftaxation of residents is fiscal considerations. The commune authorities do not have the possibility to increase the tax burden beyond the maximum statutory level. Therefore, obtaining funds for the implementation of public goals that are important for the basic local government unit may lead its authorities to fall back on this institution. Using the referendum on self-taxation of residents may also be supported by the need to include community members in the implementation of public tasks and, as a result, in the shaping of their responsibility for the functioning of their commune. The introduction of self-taxing solely on the basis of a commune referendum allows performing tasks recognized by the local community as important enough so that it expresses the will to incur additional burdens above those resulting from tax laws (Niezgoda, 2004: 618). A referendum on self-taxation of residents should above all be applied to the implementation of communal tasks which concern the entire local community. Therefore, this institution could be used in the implementation of tasks such as construction of water supply and sewage networks, sewage treatment plants, taking over the duties of property owners as regards commune waste disposal (Palarz, 2015).

\section{Referendum Procedure}

Pursuant to the provisions of Art. 4 of the Act on the local referendum, the initiation of the referendum procedure may take place as a result of a resolution adopted 
Referendum for Self-Taxation as a Form of Participation of Commune Residents...

by the commune council or an application submitted by a group of residents. In the case of the first option, the decision-making and reviewing body shall adopt a resolution on conducting the referendum with an absolute majority of votes of its statutory panel. The resolution must meet the requirements specified in Art. 9/2 and Art. 9/3 of the Act. Therefore, it is necessary for the resolution to include: a question or questions of the referendum, the date of the referendum, a sample ballot paper and sample overlays for ballot papers made in Braille, a calendar of activities related to conducting the referendum. It is also indispensable that the commune council's resolution should indicate the purpose or objectives and the principles of self-taxation. It should be assumed that the resolution should specify: the purpose of the funds collected in this manner, the method of their collection, whether the payment is to be made in a lump sum or paid in installments, possible criteria differentiating the number of payments made. Subsequently, the resolution of the commune's decision-making and reviewing body regarding the holding of the referendum shall be announced in the voivodship official journal, and, in addition, placed immediately on posters or announced in another manner usually adopted in a given local government unit.

In turn, the initiation of a referendum procedure at the request of residents requires, pursuant to the provisions of Art. 11/1 of the Act, that the application is made by a group of at least five citizens who have the right to elect their commune council. It should be noted that the active elective right to elect commune council is afforded, in accordance with Art. 10/1/3 of the Electoral Code of 5 January 2017 to Polish citizens and European Union citizens who are not Polish citizens, who no later than the date of the vote turn 18 years old and permanently reside in the area of this commune. The mentioned entities cannot, however, be: deprived of public rights by a final court decision, deprived of electoral rights by a final decision of the State Tribunal, incapacitated by a final court decision. A group of commune residents entitled to submit a request for a referendum was given an obligation to fulfill statutory obligations, which determine the correct course of the referendum procedure. The first of these consists in a written notification to the executive body of the commune with the intention to put forward a referendum initiative. Then, in accordance with the provisions of Art. 13 of the Act, the initiator of the referendum is obliged to notify, at their own expense, residents of the commune about the subject of the intended referendum. Information about the intended referendum should include the question or questions, as well as the objective or objectives and the principles of self-taxation. In the commune, dissemination of information about the planned referendum takes place in a manner customarily adopted in a given local government unit (it is possible to place the information on the notice board in the commune office, to display posters in places intended for public announcements). The literature points out that burdening residents of self-governing communities 
with the costs of providing information on the subject of the intended referendum is a factor that weakens the ability of community members to initiate a referendum. On the other hand, the need to bear the costs of the announcement may be a barrier to the emergence of various referendum initiatives that will not gain public support (Uziębło, 2008: 69).

Another obligation on the group of residents initiating the local referendum is specified in Art. 14 of the Act. Its essence is the collection of signatures of residents entitled to elect the decision-making commune authority, interested in supporting the initiative. Signatures should be collected on cards, the elements of which were defined by law, within 60 days from the day of notifying the commune's executive body of the intention to put forward a referendum initiative. The time limit is of a preclusion nature, which cannot be restored or extended. However, the case presented to the residents on the cards, while seeking their support, should be equated with the case proposed to be settled by the referendum, as specified in the request for conducting the referendum by means of questions (Supreme Administrative Court: II OSK 825/14).

In addition to the duties assigned to the group of commune residents who are the initiators of the referendum, the legislator regulated in detail the duties of the commune bodies regarding proceeding with the request of the referendum initiator. According to Art. 15/1 of the Act, the executive body of the commune, after receiving the residents' request, shall immediately confirm this fact in writing. Then they pass the request to the chairman of the commune council, in order for the request for a referendum to be verified by the decision-making body. Pursuant to the provisions of Art. 17/1 of the Act, the decision-making body of a local government unit shall adopt a resolution on holding a referendum if the residents' request meets the requirements of the Act and does not lead to decisions contrary to the law. The decision-making body is bound by the content of the request. The manner in which the legislator recognizes the criteria for the assessment of the request means that determining the existence of only one of the two flaws of the request gives a sufficient basis for its rejection (Voivodship Administrative Court: III SA / Lu 689/12). It is not admissible, however, that the authority, rejecting the residents' request regarding the referendum, should be guided by non-normative criteria, such as, for example, the purpose of holding a referendum (Voivodship Administrative Court: III SA/Lu 750/11). A resolution on the holding of a referendum or a resolution on rejecting the residents' request shall be taken by the commune council not later than within 30 days from the date of submitting the request for the initiative of holding a referendum to the executive body of the self-governing community. The resolution is subject to the announcement in the voivodship official journal, 
Referendum for Self-Taxation as a Form of Participation of Commune Residents...

and, moreover, immediate display on posters or announcement in another way customarily adopted in a given commune.

The Act on local referendum sets out the rules, sources, and method of financing a referendum, and the scope of these regulations affects the course and result of the referendum. Representatives of science indicate that the financing of a referendum was based on the principles of transparency, covering costs from public funds (from the budget of a local government unit or from the state budget), covering the expenses of the referendum initiator from own sources, transferring by the initiator of the surplus of obtained funds for referendum purposes to a charity institution (Olejniczak-Szałowska, 2002: 205). Among the listed principles, the most important influence on the frequency of initiating a referendum on self-taxation of residents is the principle of covering the expenses of the initiator of the referendum from own sources. This principle has been expressed in Art. 42 of the Act and covers all activities undertaken by the initiator in the conducted referendum. These include both activities performed in connection with the initiative to hold a referendum, as well as activities carried out as part of the referendum campaign. Expenses incurred in connection with the taking up are to be covered from own sources understood as legally permitted sources of financial contributions (Czaplicki, 2007: 151). The problem of obtaining financial contributions will become apparent when a group of residents of a commune will be the initiator of the referendum. This group will in principle be forced to finance all activities from own resources of natural persons who form that group. It should be noted that the expenses of the initiator of the referendum are relatively large and include, among others, fees for using the mass media, costs of producing and distributing referendum materials, costs of organizing meetings with residents (Olejniczak-Szałowska, 2002: 207). In view of the above, it can be concluded that the regulations adopted in Art. 42 of the Act contribute to the limitation of the referendum initiative. On the other hand, they may be helpful in achieving a state where it would be undertaken when it was supported by the interest of as many of the commune's residents as possible, rather than by the needs of a narrow group of self-governing community members.

The implementation of the principle of transferring the surplus of obtained funds for referendum purposes to a charity institution may also be problematic for the initiator of the referendum. This principle has its normative dimension in the provisions of Art. 46 of the Act. The legislator, obliging the initiator of the referendum to transfer the surplus of funds obtained, also established the requirement to include in the financial statements information on the purpose for which the surplus was transferred. Difficulties related to the implementation of the principle in question may consist in proper identification of the charity institution and in selecting it. In determining which of the existing institutions conduct charitable activities, their 
informal records or registers may prove helpful. The problem may, however, be the choice of such an institution, especially in a situation where a group of residents is the initiator of a local referendum. It would then be reasonable for the persons initiating the referendum procedure to present a common position reached as a result of agreement or vote. The situation is complicated by the fact that people bound by a common referendum goal may have different views on the distribution of surplus funds obtained for activities related to the referendum (Uziębło, 2008: 170-171).

Relatively, the implementation of the principle of transparency should give the initiator of the referendum fewest complications. This principle is embodied in the obligation resultant from Art. 45 of the Act to prepare financial statements on income and expenses related to the referendum. The fulfillment of this obligation rests with the representative of the initiator of the referendum, who is obliged to submit the financial statements to the executive body of the commune within three months from the day of the referendum. The statements are to be drawn upon a form prepared according to an officially agreed template. Then, the executive body makes the statements available to the residents of the local governing community.

The Act on the local referendum regulates the conditions for the validity of the referendum and the recognition of its result as decisive. The legal solutions adopted in this respect seem to have a significant impact on the frequency of initiating referendum procedures in the subject of residents' self-taxation for public purposes. The literature points out that the final result of the referendum is determined by the number of residents of a given local community participating in it and the content of the answers they provide to the questions formulated in the referendum. In the first case, the turnout determines the validity of the referendum. In the second, the manifestation of citizens' expectations as to the subject of the referendum decides whether the result of the referendum will be decisive or not. At the same time, specific legal consequences are triggered only by a valid referendum (Dauter, 2007: 179).

Pursuant to the provisions of Art. 55 of the Act, a referendum is valid if at least $30 \%$ of those entitled to vote took part in it. The number of persons entitled to vote results from the electoral roll. In turn, the number of people who took part in the voting is determined on the basis of the number of valid ballot papers taken out of the ballot box. Therefore, a prerequisite for determining that the referendum has brought about a conclusive result is the right turnout. Only after stating that the conditions for the validity of the referendum have been met is it possible to proceed to determine whether the conditions under which the referendum brings about a conclusive result have been met (Olejniczak-Szałowska, 2002: 218). According to Article 56 of the Act, the result of the referendum is conclusive if more than half 
of the valid votes were cast in favor of one of the solutions in the matter subjected to the referendum. The conclusive result reflects the will of the local community regarding the subject of the referendum, expressed in a direct way during the vote. Each of those entitled to participate in the referendum expresses their will by voting for one of the solutions in the case subjected to a referendum (Dauter, 2007: 181). It should be emphasized that in relation to the local referendum on self-taxation of residents for public purposes, the legislator decided to tighten the criteria determining the conclusive result. Pursuant to the provisions of Art. 56/2 of the Act, the result of the commune referendum on self-taxation is conclusive if at least twothirds of valid votes were cast in favor of self-taxation.

In the subject literature, different views on the legitimacy of establishing higher criteria for a conclusive result of the referendum on self-taxation are presented. Supporters of this regulation argue that the need to establish it is supported by the fact that the subject of the referendum concerns matter which in principle is regulated by law. An additional argument is that the result of the referendum applies equally to all residents of a given self-governing community (Dauter, 2007: 182). It is also indicated that the two-thirds threshold of validly cast votes is too lenient and it is proposed that the threshold of support, and also the threshold of turnout, should be raised. Such a solution would serve to increase the legitimacy of introducing public burdens that are imposed on all members of the self-governing community, and not only on the commune's residents taking part in the voting (Uziębło, 2008: 206). It should be emphasized that the tightening of the criteria determining the conclusive result of the referendum on self-taxation has also been criticized in the doctrine. Its representatives point out that the introduction of strict requirements in relation to the mode of establishing self-taxation makes this institution applicable in practice only exceptionally. One should justify the doubts as to whether the intention of the legislator was to establish a difficult to implement and costly procedure of taking a decision on self-taxation if its consequences were to be residents' nonbinding position as to their will to incur additional costs for the implementation of a public task (Niezgoda, 2004: 621).

Pursuant to Art. 65 of the act, if the referendum ends with a conclusive result in the matter subjected to the referendum, the competent authority of the local government unit shall immediately undertake actions to implement it. If the subject matter of the referendum was self-taxation of residents for public purposes, the commune council will be the Competent authority. It is obliged to undertake actions that bring about the will of the residents. The nature of these actions has not been specified, which should make one conclude that they may be all activities within the scope of the competences of the decision-making body, aimed at the implementation of the referendum decision (Olejniczak-Szałowska, 2002: 253). The deadline for the 
implementation of the referendum decision has not been specified by the legislator. An instructional character is attributed to it due to the lack of sanctions for its violation. Therefore, a de lege ferenda proposal was formulated in the literature that Art. 65 of the Act should be amended in such a way so that the ending date is placed in the norm (Wierzbica, 2014: 150). In the current legal status, guarantees for the implementation of a referendum decision can be sought in the provisions of Art. 101a of the commune self-government act (Olejniczak-Szałowska, 2002: 260). They shape the right of everyone to file a complaint at the administrative court in a situation where the competent commune body does not perform activities prescribed by law.

\section{Conclusions}

The existing legal solutions specify the conditions for initiating a referendum procedure regarding self-taxation of residents for public purposes and its conduct in such a way that it may end in a conclusive result. Although the regulations provide the residents of the commune with the opportunity to personally participate in shaping the income of their self-governing community, the institution of the referendum is relatively rarely used. The referendum initiatives undertaken so far, as a result of which the residents of the commune took on additional obligations for it, concerned: introducing flat-rate fees for the disposal of solid waste, fees for health care. A referendum on self-taxation was often carried out together with voting on other matters - alongside presidential elections, national referendums, parliamentary elections (Piasecki, 2005: 108-109). It may be assumed that the reason for the marginal use of the institution of a referendum are legal solutions establishing for the referendum initiator requirements of informing on the subject of the intended referendum, respecting the rules for financing a referendum, as well as shaping the threshold of turnout or a higher threshold of support. However, it should be borne in mind that a referendum on self-taxation is an expensive, timeconsuming institution, requiring substantial preparation of the commune's residents as to the subject of the vote, and to a large extent causing taxpayers' reluctance to increase their public and legal burdens.

\section{References}

Brzeziński, B.: Glosa do wyroku Naczelnego Sądu Administracyjnego z dnia 21 października 1993 r., SA/Wr 1171/93 (Commentary to the decision of the Supreme Administrative Court of 21 October 1993, SA/Wr 1171/93 ), Przegląd Orzecznictwa Podatkowego (Tax Case Law Review) no. 4 (1995). 


\section{Referendum for Self-Taxation as a Form of Participation of Commune Residents...}

Gliniecka, J.: Opłaty publiczne w Polsce. Analiza prawna i funkcjonalna (Public levies in Poland. Legal and functional analysis), Bydgoszcz-Gdańsk: Oficyna Wydawnicza Branta, 2007.

Kornberger-Sokołowska, E.: Zasada adekwatności w systemie finansów samorządu terytorialnego w Polsce (The principle of adequacy in the system of finance of the territorial self-government in Poland), Warszawa: LexisNexis, 2013.

Czaplicki, K.W.: Komentarz do art. 43 (Commentary to Article 43), in: Czaplicki, K.W. et al. (eds.): Ustawa o referendum lokalnym. Komentarz (Act on local referendum. Commentary), Warszawa: Wolters Kluwer, 2007.

Dauter, B.: Komentarz do art. 55 (Commentary to Article 55), in: Czaplicki, K.W. et al. (eds.): Ustawa o referendum lokalnym. Komentarz (Act on local referendum. Commentary), Warszawa: Wolters Kluwer, 2007.

Gomułowicz, A. et al.: Podatki i prawo podatkowe (Taxes and tax law), Warszawa: LexisNexis, 2013.

Kisielewicz, A.: Komentarz do art. 14 (Commentary to Article 14), in: Czaplicki, K.W. et al.: Ustawa o referendum lokalnym. Komentarz (Act on local referendum. Commentary), Warszawa: Wolters Kluwer, 2007.

Kryczko, P.: Komentarz do art. 54 (Commentary to Article 54), in: Chmielnicki P. (ed.): Ustawa o samorządzie gminnym. Komentarz (Act on commune self-government. Commentary), Warszawa: LexisNexis, 2013.

Mordwiłko, J.: Referendum gminne w świetle prawa i praktyki (Commune referendum in the light of law and practice), in: Piekara, A. et al.: Samorząd terytorialny. Zagadnienia prawne i administracyjne (Territorial self-government. Legal and administrative issues), Warszawa: Wydawnictwo Prawnicze Sp. z o.o., 1998.

Niezgoda, A.: Samoopodatkowanie a bezpośrednie formy sprawowania władzy na szczeblu lokalnym (Self-taxation and direct forms of exercising power at the local level), in: Ura, E. (ed.): Jednostka, państwo, administracja - nowy wymiar (Individual, state, administration - new dimension), Rzeszów: Mitel, 2004.

Olejniczak-Szałowska, E.: Prawo do udziału w referendum lokalnym (The right to participate in a local referendum), Łódź: Wydawnictwo Uniwersytetu Łódzkiego, 2002.

Olejniczak-Szałowska, E.: Referendum lokalne w świetle ustawodawstwa polskiego (Local referendum in the light of Polish legislation), Warszawa: Difin, 2002.

Olejniczak-Szałowska, E.: Referendum lokalne (Local referendum), in: Stahl, M. et al. (eds.): Encyklopedia samorządu terytorialnego, cz. 1, Ustrój (Encyclopedia of territorial self government. Part 1. Regime), Warszawa: Difin, 2010.

Palarz, H.: Przyłączenie do sieci wodociągowo-kanalizacyjnej. Aspekty prawne (Connecting to a water supply and sewage network. Legal aspects), Warszawa: Wolters Kluwer, 2015.

Piasecki, A.K.: Referenda w III RP (Referendums in the Third Polish Republic), Warszawa: Wydawnictwo Naukowe PWN, 2005. 
Skoczylas, A. et al.: Komentarz do art. 170 (Commentary to Article 170), in: Safjan, M. et al. (eds.): Konstytucja RP. Tom II. Komentarz. Art. 87-243 (Constitution of the Republic of Poland. Volume II. Commentary. Articles 87-243), Warszawa: C.H. Beck, 2016.

Uziębło, P.: Ustawa o referendum lokalnym. Komentarz (Law on the local referendum. Commentary), Warszawa: Wolters Kluwer, 2008.

Wierzbica, A.: Referendum i wybory oraz zarządzenia i uchwały jednostek samorządu terytorialnego (Referendum and elections, ordinances and resolutions of local government units), Warszawa: LexisNexis, 2014.

Zimmermann, J.: Prawo administracyjne (Administrative law), Kraków: Zakamycze, 2005.

Council of Europe, European Charter of Local Self-Government of 15 October 1985.

PL: Constitution of the Republic of Poland of 2 April 1997, as amended.

PL: Act of 8 March 1990 on commune self-government, as amended.

PL: Act of 5 June 1998 on county self-government, as amended.

PL: Act of 5 June 1998 on voivodship self-government, as amended.

PL: Act of 15 September 2000 on local referendum, as amended.

PL: Electoral Code of 5 January 2011, as amended.

PL: Supreme Administrative Court: II OSK 825/14.

PL: Voivodship Administrative Court: III SA/Gd 183/16.

PL: Voivodship Administrative Court: III SA/Lu 689/12.

PL: Voivodship Administrative Court: III SA/Lu 750/11. 